\title{
MANAJEMEN TAMAN TERINDAH (KAJIAN ALTERNATIF PENGEMBANGAN PENDIDIKAN KHUSUS)
}

\author{
Dwi Hanggoro \\ Widyaiswara Muda PPSDM Kemendagri Regional Yogyakarta
}

\begin{abstract}
Abstrak
Sebuah kajian alternatif pengembangan pendidikan khusus bagaimana implementasi dan dampak dari pengembangan manajemen Taman Terindah yang dilaksanakan di salah satu sekolah yang memberikan pelayanan terhadap Anak Berkebutuhan Khusus (ABK) yaitu SLB Negeri Boyolali. Adapun tahapan implementasinya adalah; (1) perumusan konsep, (2) implementasi, (3) evaluasi. Hasil dari penerapan konsep Manajemen Taman Terindah menunjukkan realisasi program kemandirian sebesar $80 \%$, keterampilan $50 \%$ dan ibadah terealisasi $83 \%$. Kesimpulannya dengan mengimplementasikan konsep Manajemen Taman Terindah ada peningkatan realisasi progam kemandirian, keterampilan dan ibadah dibanding dengan sebelum ada penerapan Manajemen Taman terindah.
\end{abstract}

Kata Kunci: manajemen taman terindah; alternatif pengembangan; kemandirian; keterampilan; ibadah

\section{TAMAN TERINDAH MANAGEMENT (ALTERNATIVE STUDY OF SPECIAL EDUCATION DEVELOPMENT)}

\author{
Dwi Hanggoro \\ Young Widyaiswara PPSDM Ministry of Home Affairs Yogyakarta Regional
}

\begin{abstract}
An alternative study of the development of special education on how the implementation and impact of the development of the most beautiful park management is carried out in one of the schools that provide services for children with special needs, namely SLB Negeri Boyolali The implementation stages are; (1) concept formulation, (2) implementation, (3) evaluation. The results of the application of the concept of the Most Beautiful Park Management showed that the realization of the independence program was $80 \%$, skills were $50 \%$ and worship was realized $83 \%$. The conclusion is that by implementing the concept of the Most Beautiful Park Management, there is an increase in the realization of the independence, skills and worship program compared to before the implementation of the most beautiful Park Management.
\end{abstract}

Keywords: taman terindah management; development alternatives; independence; Skills; worship 


\section{PENDAHULUAN}

Salah satu lembaga pendidikan untuk anak berkebutuhan khusus (ABK) yaitu Sekolah Luar Biasa, dan Sekolah Luar Biasa yang ideal adalah sekolah yang mampu mengembangkan potensi peserta didik berkebutuhan khusus sesuai dengan potensi yang dimiliki, hal ini seiring dengan tujuan Undang-undang No 20 tahun 2003 pasal 3 yaitu: berkembangnya potensi peserta didik agar menjadi manusia yang beriman dan bertakwa kepada Tuhan Yang Maha Esa, berakhlak mulia, sehat, berilmu, cakap, kreatif, mandiri, dan menjadi warga negara yang demokratis serta bertanggung jawab. Dengan demikian diperlukan sebuah sekolah dimana anak-anak dapat merasakan betapa senang dan nyamannya belajar tanpa mengalami hal-hal yang membuat dirinya menderita. Mereka dapat belajar, bermain, dan mengekspresikan dirinya dengan maksimal.

Dalam perkembangannya sekolah tak lagi dipandang sebagai taman peserta didik yang menyenangkan. Banyak kejadian yang malah membuat anak menderita karena perlakuan kasar dari teman atau bahkan gurunya. Kasus bullying atau pelecehan seksual kerap mewarnai perjalanan anak-anak dalam menuntut ilmu di sekolah. Banyaknya peraturan sekolah dengan dalih untuk pendisiplinan malah membuat anak menjadi terkekang dan tidak bebas berekspresi. Belum lagi, di hari pertama masuk sekolah rata-rata peserta didik harus menjalani Masa Orientasi Peserta Didik Baru yang seringkali melenceng dari tujuan utamanya. Guru yang terkesan kurang perhatian dan terlihat tidak ramah di depan murid terlebih lagi dalam menghadapi Anak Berkebutuhan Khusus yang membutuhkan perhatian lebih dari pada anak normal, membuat sekolah bukan lagi tempat yang menyenangkan bagi Anak Berkebutuhan khusus layaknya sebuah taman tetapi kondisi tersebut justru dapat membuat anak malas untuk pergi ke sekolah.

Menurut Permendikbud Nomor 21 Tahun 2015 tentang Penumbuhan Budi Pekerti (PBP) dinilai perlu segera dilakanakan di setiap sekolah tanpa kecuali. Tujuannya tak lain untuk menumbuhkan sikap, nilai, dan karakter positif pada diri peserta didik. Dengan gerakan Pertumbuhan Budi Pekerti ini diharapkan pula terjalin hubungan yang lebih erat antara orang tua peserta didik dengan pihak sekolah.

Untuk mewujudkannya diperlukan seperangkat pemikiran mendasar, di antaranya dengan mengelola kekuatan sekolah secara terpadu baik guru, orang tua, komite sekolah, dan peserta didik 
sebagai subjek pendidikan. Proses tersebut diselenggarakan dengan berorientasi pada pembudayaan, pemberdayaan, pembentukan akhlak mulia, budi perkerti luhur, watak, kepribadian, karakter unggul, dan berbagai kecakapan hidup.

Alangkah bangganya menyaksikan sebuah kelas di suatu SLB, seorang guru menyambut kehadiran peserta didik dengan senyuman dan sapaan hangat kepada masing masing peserta didik, membuat suasana menyenangkan di lingkungan sekolah dengan memutar lagulagu anak-anak, lagu kerohanian atau lagulagu wajib nasional sebelum pelajaran dimulai melalui audio yang dimiliki sekolah, membimbing dengan persiapan yang baik, memahami karakter semua peserta didiknya, peserta didik gembira karena tidak ada yang lengah dari perhatian guru, dibimbing sesuai kemampuannya, di waktu istirahat di isi dengan kegiatan sholat dhuha berjamaah dan di siang hari ketika adzan duhur tiba semua peserta didik dan guru menuju masjid untuk sholat dzuhur berjamaah, guru membantu peserta didik berwudlu, sholat dan merapikan pakaiannya. Setiap hari jum `at jam 11.00 12.00 WIB peserta didik yang beragama Kristen mengikuti pembinaan mental dari guru Agama Kristen.
Suasana ideal inilah yang belum maksimal dilaksanakan di SLB Negeri Boyolali, sekolah baru yang merupakan peralihan dari SDLB Negeri Pulisen Boyolali. Banyak faktor yang menyebabkan belum maksimalnya pencapaian tujuan pendidikan sebagaimana tercantum dalam UU No 20 tahun 2003 pasal 3, salah satu faktor yang paling dominan adalah kurang maksimalnya peran kepala sekolah dalam menumbuhkan potensi warga sekolah, baik peserta didik, guru, komite sekolah maupun masyarakat di sekitar sekolah.

Kepala Sekolah adalah pimpinan tertinggi di sekolah, pola kepemimpinannya akan sangat berpengaruh dan sangat mementukan kemajuan sekolah, karena kepala sekolah memiliki fungsi strategis dalam mengembangkan sekolah, selain fungsi pemimpin pendidikan kepala sekolah juga berfungsi sebagai edukator, manajer, administrator, supervisor, motivator dan inovator E. Mulyasa (2009).

Besarnya fungsi kepala sekolah dalam kemajuan sebuah sekolah maka kepala sekolah dituntut untuk bekerja penuh dengan dedikasi dan inovasi sehingga mampu mewujudkan tujuan pendidikan yaitu mengembangkan potensi peserta didik agar menjadi manusia yang beriman dan bertakwa kepada Tuhan Yang 
Maha Esa, berakhlak mulia, sehat, berilmu, cakap, kreatif, mandiri, dan menjadi warga negara yang demokratis serta bertanggung jawab.

Untuk mewujudkan hal tersebut, maka dirumuskan desain konsep pengembangan sekolah yang terencana dan berkesinambungan. Manajemen Taman Terindah adalah salah satu alternatif pengembangan sekolah yang penulis terapkan mulai tahun 2019 setelah penulis ditetapkan sebagai kepala sekolah definitif di Sekolah Luar Biasa Negeri Boyolali.

Pemilihan kata Taman Terindah penulis pilih karena merupakan sebuah tempat kondusif yang harus ada pada setiap lembaga pendidikan, sebuah kalimat yang singkat dan sederhana namun memiliki implikasi yang sangat luas dan dalam. Dengan harapan Taman Terindah menjadi inspirasi dan motivasi bagi seluruh warga Sekolah Luar Biasa Negeri Boyolali, khususnya dalam pengembangan potensi peserta didik.

Berdasarkan latar belakang masalah di atas maka dapat dirumuskan permasalahan sebagai beriku: (1) bagaimana implementasi manajemen Taman Terindah dalam pengembangan pendidikan khusus di Sekolah Luar Biasa Negeri Boyolali; (2) bagaimana dampak manajemen Taman Terindah dalam pengembangan pendidikan khusus di Sekolah Luar Biasa Negeri Boyolali.

Penyelesaian

permasalahan pengembangan sekolah dengan pendekatan Manajemen Taman Terindah di SLB Negeri Boyolali dengan mengoptimalkan peran seluruh sumberdaya yang ada di sekolah yang meliputi peserta didik, guru, karyawan, orang tua, komite sekolah dan masyarakat serta sarana dan prasarana yang ada sehingga dapat mewujudkan pendidikan yang mampu mengembangkan potensi peserta beriman dan bertaqwa kepada Tuhan Yang Maha Esa, pintar, sehat terampil dan mandiri.

Tahapan operasional penerapan Manajeman Taman Terindah terdiri dari beberapa langkah antara lain: (a) menumbuhkan kesadaran warga sekolah terhadap hak dan kewajibannya, baik hak dan kewajiban sebagai kepala sekolah, guru, peserta didik, maupun karyawan; (b) merumuskan konsep strategi pengembangan bersama dengan guru, karyawan dan komite sekolah; (c) merumuskan langkah dan jadwal penerapan Manajemen Taman Terindah bersama dengan guru, karyawan dan komite sekolah; (d) menyediakan sarana dan pra sarana pendukung pengembangan 
Manajemen Taman Terindah; (e) sosialisasi Manajemen Taman Terindah dilakukan terhadap semua warga sekolah sehingga semua memahami konsep dan implementasinya; (f) implementasi Manajemen Taman Terindah dilakukan sesuai dengan konsep dan tahapan yang sudah dirumuskan, Implementasi dimulai pada awal tahun pelajaran 2019/2020.

Evaluasi implementasi Manajemen Taman Terindah dilaksanakan tiap minggu, bulan, dan tahun oleh kepala sekolah bersama guru dan komite sekolah.

\section{STRATEGI PEMECAHAN MASALAH}

Alasan memilih Manajemen Taman Terindah sebagai salah satu alternatif pengembangan pendidikan khusus di Sekolah Luar Biasa Negeri Boyolali dilandasi pemikiran bahwa untuk merubah sebuah kebiasaan memerlukan program yang terancana, efektif dan terukur.

Pemilihan istilah Taman Terindah dalam konsep strategi pengembangan memiliki dua makna, pertama Taman Terindah adalah sebuah tempat pembelajaran yang nyaman, aman, damai, menyenangkan dan mampu mempersiapkan masa depan bagi peserta didik. Kedua Taman Terindah adalah sebuah akronim dari Tanamkan_Anak MANdiri, TERampil dan rajIN ibaDAH, yang merupakan bagian dari tujuan pendidikan yaitu mengembangkan potensi peserta didik agar menjadi manusia yang mandiri, terampil dan bertaqwa dan beriman kepada Tuhan Yang Maha Esa.

Perpaduan antara semboyan taman terindah yang menyatu pada setiap warga sekolah dan tahapan konsep yang terencana yaitu mengembangkan potensi anak agar menjadi mandiri, terampil dan rajin ibadah merupakan energi besar untuk merealisasikan semua program.

Mengantarkan anak mandiri, terampil dan rajin ibadah adalah sebuah semangat besar SLB Negeri Boyolali dan dapat terealisasikan ketika setiap warga sekolah bersinergi, untuk sebuah konsep yang sama, terprogram, terjadwal,terlaksana, teramati dan terevaluasi dengan baik.

\section{Langkah Pemecahan Masalah}

Langkah pertama, penumbuhan kesadaran dilakukan dengan sambung rasa baik secara formal maupun in formal, secara formal kepala sekolah mengadakan pertemuan dengan guru, karyawan dan komite sekolah dengan inti pertemuan menggali sejauh mana pemenuhan keseimbangan antara hak yang didapat dan kewajiban yang sudah dilaksanakan. Sambung rasa ini formal kepala sekolah melakukan wawancara dan observasi kepada warga sekolah untuk meminta 
saran dan pendapat terhadap kemajuan sekolah. Hal ini membuka kesempatan yang lebih luas untuk memecahkan persoalan yang dihadapi anak, baik terkait dengan masalah belajar maupun dengan masalah pergaulan di sekolah. Guru tidak perlu khawatir dengan diantarnya anak ke sekolah oleh orang tua, akan menyebabkan anak menjadi pribadi yang tidak mandiri.

$$
\text { Langkah kedua penerapkan }
$$

Manajemen Taman Terindah, kepala sekolah merumuskan beberapa langkah stretegis. Beberapa langkah strategis tersebut antara lain yang (a) merumuskan konsep Manajemen Taman Terindah. Perumusan konsep Manajemen Taman Terindah dilakukan oleh kepala sekolah bersama dengan guru dan komite sekolah; (b) merumuskan langkah dan jadwal penerapan Manajemen Taman Terindah bersama dengan guru, karyawan dan komite sekolah; (c) menyediakan sarana pendukung pengembangan Manajemen Taman Terindah. Sarana yang disediakan pihak sekolah antara lain adalah audio yang tersambung di setiap ruangan sehingga dapat memudahkan penyampaian informasi, bel otomatis di setiap jam pelajaran dan dipergunakan untuk memutar lagu-lagu sebelum kegiatan belajar mengajar dimulai; (d) sosialisasi Manajemen Taman Terindah dilakukan terhadap semua warga sekolah sehingga semua memahami konsep dan implementasinya. Sosialisasi ini dilakukan dalam rapat komite sekolah bersama wali murid dan guru beserta kepala sekolah.

Pelaksanaan Manajemen Taman Terindah Beberapa program yang dilaksanakan adalah: (1) memutar lagulagu anak dan lagu nasional sebelum jam pelajaran dimulai melalui audio yang sudah terpasang disekolah yang bertujuan untuk menambah semangat peserta didik dan menumbuhkan suasana yang menyenangkan sebelum pelajaran dimulai. Musik dapat membantu peserta didik untuk berfikir lebih jernih; (2) guru menyambut peserta didik dengan senyuman dan pelukan hangat sebelum masuk ke kelas sehingga perlakuan yang menyenangkan saat anak belajar atau perlakuan yang diberikan guru sebelum masuk kelas dapat memberikan stimulasi menyenangkan untuk anak sehingga membuat anak menjadi semangat dalam belajar, dan membuat nyaman peserta didik yang berada di dalamnya; (3) menyediakan tempat atau ruang tunggu yang representatif untuk wali murid,adanya ruang tunggu memudahkan proses komunikasi antara guru dan wali murid tentang perkembangan anak didik setiap harinya sehingga guru lebih mudah 
memberikan masukan kepada wali murid tentang perkembangan peserta didik dan program-program yang dapat dilakukan selama di rumah; (4) kegiatan masa orientasi peserta didik baru.

Pada Masa orientasi Peserta Didik Baru dilakukan beberapa kegiatan-kegiatan yang edukatif dan menyenangkan. Kegiatan-kegiatan tersebut antara lain adalah kegiatan Out bond di lapangan sekolah. Kegiatan ini bertujuan untuk pengakraban antar peserta didik dan guru. Permainan yang disusun melibatkan kerjasama tim dan tentunya aktivitas yang menyenangkan untuk semua. Disamping itu, beberapa permainan dapat meningkatkan kemampuan motorik anak berkebutuhan Khusus,seperti rapat sekolah diselenggarakan pada awal bulan Juni 2019. Rapat sekolah di ikuti oleh Komite sekolah, Guru dan Karyawan, serta Wali murid. Rapat dengan agenda mendengarkan dan sambung rasa antara berbagai pihak dan menggali sejauh mana hak yang dan kewajiban yang sudah dilaksanakan, serta meminta saran dan pendapat berbagai pihak untuk kemajuan sekolah. Rapat sekolah selanjutnya diselenggarakan pada pertengahan semester pertama setelah disusunya Manajemen Taman Terindah oleh kepala sekolah. Rapat sekolah yang selanjutnya membahas tentang sosialisasi Manajemen Taman Terindah kepada guru dan karyawan, serta wali murid.

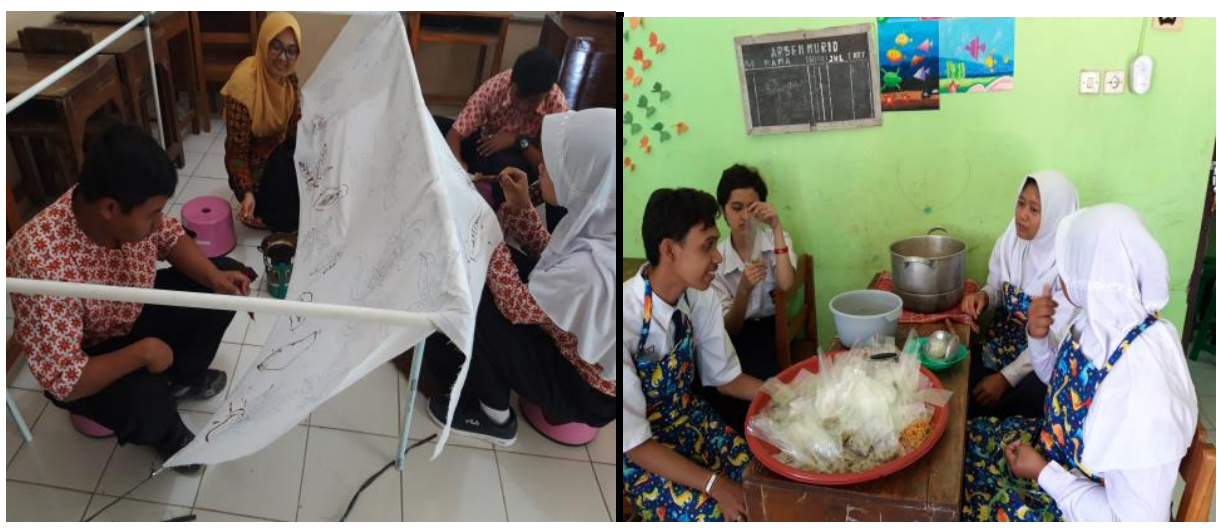

Gambar 1. Kegiatan pembelajaran membatik dan tata boga di Sekolah melatih keterampilan dan kemandirian Peserta Didik 
Penerapan Manajemen Taman terindah.

Penerapan Manajemen taman terindah (Tanamkan Anak MANdiri, TERampil dan rajIN ibaDAH) adalah sebagai berikut: (1) mandiri dimana program kemandirian peserta didik melibatkan semua peserta didik dari kelas persiapan sampai SMALB. Program kemandirian peserta didik dilaksanakan oleh guru kelas masing masing disesuaikan dengan tingkat perkembangan peserta didik. Kegiatan kemandirian peserta didik pada kelas awal difokuskan pada ADL (Activity Daily Living) atau kemandirian mengurus diri sendiri, pada kelas besar diarahkan pada kegiatan persiapan untuk hidup mandiri setelah lulus sekolah; (2) terampil dimana program pembelajaran difokuskan kepada pengembangan potensi peserta didik secara maksimal, sehingga peserta didik "terampil" dalam menjalani perkembangannya dimana program keterampilan yang telah dilaksanakan di SLB N Boyolali antara lain Membatik, Menjahit/Tata Busana, Hidroponik, Tata boga dan penjualan dan Salon; (3) rajin ibadah dimana program peningkatan keimanan dan ketaqwaan menjadi program terpadu dalam pembelajaran, dengan tujuan peserta didik rajin dalam beribadah baik di sekolah maupun di rumah. Program peningkatan keimanan meliputi Sholat Dhuha berjamaah, Pengajian Guru dan peserta didik beserta walinya, Jamaah sholat Dzuhur, Kegiatan Pesantren Kliat.

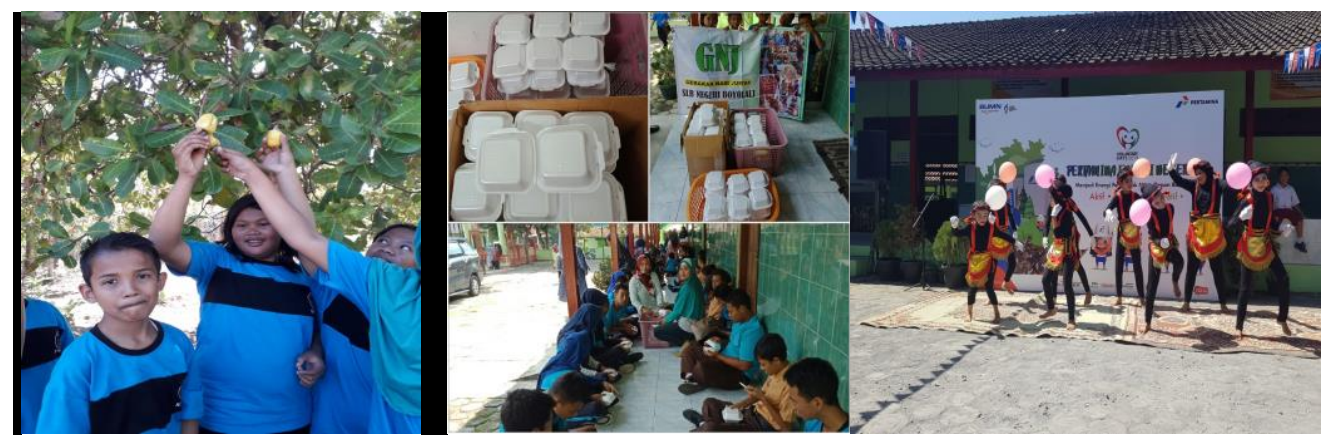

Gambar 2. Peserta Didik belajar di luar kelas, infaq untuk GNJ (Gerakan Nasi Jum'at), pentas seni tari berlatih Kemandirian, Keterampilan dan Rajin Ibadah 


\section{Evaluasi}

Evaluasi manajemen taman terindah dilaksanakan secara bertahap diantaranya: (1) evaluasi mingguan dilaksanakan oleh guru kelas dengan mengacu pada lembar kontrol peserta didik, evaluasi dilaksanakan setiap hari Jum `at dengan meminta lembar kontrol dan mengganti dengan lembar kontrol yang baru untuk 1 pekan berikutnya; (2) evaluasi bulanan dilaksanakan pada hari Jum`at pekan terakhir,evaluasi bulanan dipimpin oleh kepala sekolah untuk mendengarkan laporan guru kelas lalu hasil laporan dijadikan pedoman untuk perbaikan pada bulan berikutnya; (3) evaluasi tahunan dilaksanakan pada bulan Juni, melibatkan guru, karyawan dan komite sekolah, evaluasi tahunan bertujuan mengevaluasi progam satu tahun dan menyusun kebijakan tahun berikutnya.

Tabel 1. Jadwal Pelaksanaan Manajemen Taman Terindah

\begin{tabular}{|l|l|l|l|l|l|l|l|l|l|l|l|l|l|l|}
\hline No & Kegiatan & Juni & Juli & Ags & Sep & Okt & Nop & Des & Jan & Feb & Mar & Apl & Mei & Jun \\
\hline 1. & $\begin{array}{l}\text { Perumusan } \\
\text { Konsep }\end{array}$ & & & & & & & & & & & & & \\
\hline 2. & Pelaksanaan & & & & & & & & & & & & & \\
\hline 3. & Evaluasi & & & & & & & & & & & & \\
\hline
\end{tabular}

\section{HASIL DAN PEMBAHASAN}

\section{Hasil dan Dampak Penerapan Strategi}

Keberhasilan suatu program dapat dilihat dari beberapa faktor antara lain: terlaksananya program sesuai dengan yang telah direncanakan dan hasilnya sesuai yang diharapkan. Strategi pelaksanan Manajemen Taman Terindah dalam pengembangan pendidikan khusus di SLB Negeri Boyolali memiliki dampak atau hasil yaitu sebelum penerapan Manajemen Taman Terindah.

$$
\text { Mandiri adalah program }
$$
kemandirian peserta didik belum terencana dengan baik, kegiatan pembelajaran masih terkesan monoton, hanya sekedar memenuhi kewajiban mengajar. Dengan penerapan Manajemen Taman Terindah, progam kemandirian peserta didik tersusun secara sistematis, dan berkesinambungan, berawal dari 
perencanaan, pengorganisasian dan evaluasi. Sebelum penerapan Manajemen Taman Terindah program kemandirian yang terealisasikan 16 item kemandirian dari 32 item kemandiriaan yang direncanakan atau $50 \%$, setelah penerapan manajeman taman terindah realisasi program kemandirian 24 item kemandirian dari 32 item yang direncanakan atau $80 \%$ terlaksana.

Terampil dimana sebelum penerapan manajeman taman terindah, program peserta didik terampil masih sebatas formalitas pada jam keterampilan, variasi model keterampilan masih minim, program keterampilan belum tersusun secara sistematis dan berkesinambungan. Program keterampilan setelah penerapan manajeman taman terindah menjadi program unggulan di setiap kelas, program keterampilan disusun secara sistematis dan berkesinambungan dengan kelas di atasnya, evaluasi dan laporan perkembangan kegiatan dilaksanakan secara disiplin. Untuk program keterampilan yang terealisasikan 5 keterampilan atau sebesar $50 \%$ adari 10 keterampilan yang direncanakan, yang sebelum diterapkan manajemen taman terindah hanya sebesar $30 \%$.

Rajin Ibadah dimana kegiatan keagamaan peserta didik sebelum penerapan Manajemen Taman Terindah belum terprogram dengan teratur, pelaksanaan kegiaatan belum maksimal. Setelah penerapan Manajeman Taman Terindah, kegiatan keagaam dan ibadah terprogam dengan teratur dan berkesinambungan, evaluasi aktifitas ibadah peserta didik terlaksana. Program Rajin Ibadah terealisasikan 5 Kegiatan dari 6 Kegiatan yang direncanakan atau sebesar $83 \%$.

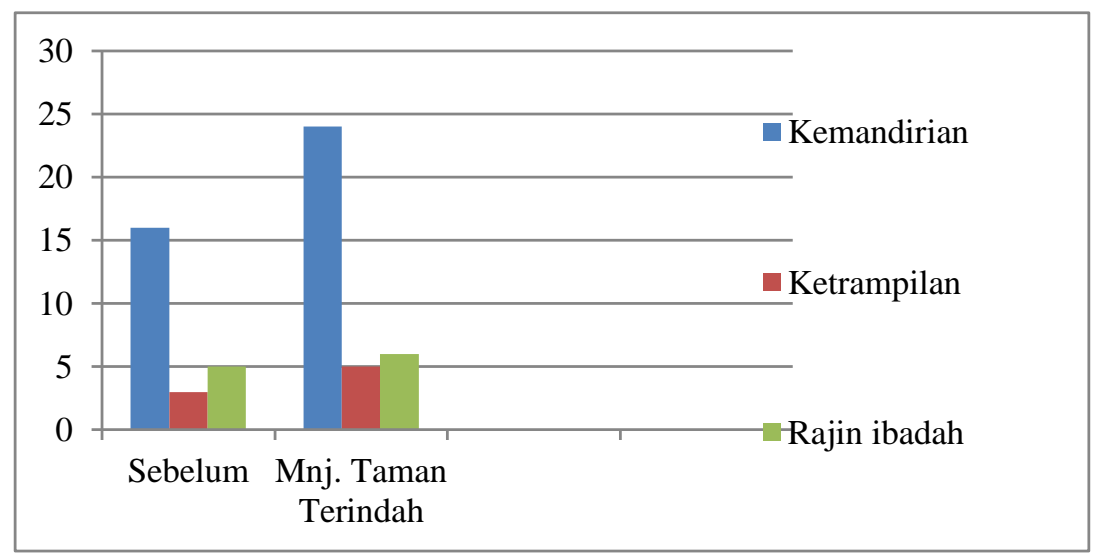

Grafik 1. Hasil Evaluasi Manajemen Taman Terindah 


\section{Kendala dan Faktor Pendukung}

Kendala yang dihadapi dalam penerapan Manajemen Taman Terindah antara lai : (1) perubahan pola pikir memerlukan proses dan pentahapan waktu yang panjang; (2) daya dukung yang belum maksimal baik dana maupun tenaga; (3) kurangnya sarana dan prasarana penunjang; (4) kepedulian dari wali murid yang belum maksimal.

Selain kendala yang dihadapi, masih banyak faktor pendukung penerapan Manajemen Taman Terindah antara lain: (1) kepala sekolah, guru, karyawan memiliki dedikasi yang tinggi dalam memajukan Sekolah Luar Biasa; (2) komite sekolah sangat mendukung semua program sekolah; dan (3) dinas pendidikan memberikan motivasi yang besar demi kemajuan Sekolah Luar Biasa Negeri Boyolali.

\section{Rencana Tindak Lanjut}

Implementasi Manajemen Taman Terindah dalam pengembangan pendidikan luar biasa di SLB Negeri Boyolali baru berjalan 1 tahun, namun sudah nampak hasilnya walaupun belum maksimal, masih banyak yang perlu dibenahi, baik pada perencanaan konsep, pengorganisaian, pelaksanaan maupun evaluasi. Pengembangan konsep selanjutnya adalah
(1) memperbaiki kekurangan-kekurangan pada pelaksanaan tahun pertama; (2) membentuk Workshop yang lebih representatif; 3) melakukan kerjasama dengan dunia usaha dan industri sebagai tempat magang peserta didik SMALB; (4) memaksimalkan forum alumni peserta didik, sebagai sarana pengembangan kewirausahaan; (5) membuat Taman Sekolah dan Tempat Bermain agar suasana sekolah layaknya sebuah taman.

\section{Simpulan}

Dari uraian yang telah dipaparkan, dapat disimpulkan: (1) Implementasi Manajeman Taman Terindah dalam pengembangan pendidikan khusus di SLB Negeri Boyolali dilakukan melalui tahapan antara lain: (a) merumuskan konsep Manajemen Taman Terindah yang meliputi konsep mandiri, terampil dan rajin ibadah.(b) melaksanakan manajemen taman terindah.(c) evaluasi implementasi Manajemen Taman Terindah.(2) hasil dari penerapan konsep Manajemen Taman terindah dalam dalam pengembangan pendidikan khusus di SLB Negeri Boyolali adalah adanya peningkatan realisasi progam kemandirian, keterampilan dan rajin ibadah dibanding dengan sebelum penerapan Manajemen Taman Terindah. 


\section{Rekomendasi}

Berdasarkan simpulan di atas maka perlu direkomendasikan sebagai berikut: (1) sekolah lebih aktif mensosialisasikan konsep Manajemen Taman Terindah kepada seluruh warga sekolah; (2) sekolah menjalin kerja sama dengan dunia usaha dan industri untuk memberikan pelatihan kepada guru dan tempat magang bagi peserta didik.

\section{DAFTAR REFERENSI}

Mulyasa,E. 2009. Kurikulum yang Disempurnakan:Pengembangan Kompetensi Dan Kompetensi Dasar. Bandung: Rosda Karya.

Permendikbud Nomor 21 Tahun 2015. Tentang Penumbuhan Budi Pekerti.

Undang-undang No. 20 Tahun 2003 Tentang Sistem Pendidikan Nasional. 